\title{
Entrepreneurial Education in Higher Institutions and Economic Development
}

\author{
Felix John Eze ${ }^{1,2} \&$ Ben E. Odigbo ${ }^{2}$ \\ ${ }^{1}$ Entreprenuership Development Centre \& Department of Marketing, University of Calabar, Nigeria \\ ${ }^{2}$ Department of Marketing, University of Calabar, Nigeria \\ Correspondence: Ben E. Odigbo, Department of Marketing, University of Calabar, Nigeria.
}

Received: September 9, 2018

Accepted: November 13, 2018 Online Published: November 24, 2018

doi:10.5539/ijms.v10n4p150

URL: https://doi.org/10.5539/ijms.v10n4p150

\begin{abstract}
This study undertook an appraisal of entrepreneurial education in higher institutions and the correlation to youths' economic empowerment national economic development. It was prompted by the problem of growing rate of unemployment amongst the country's youth population especially the young graduates. The objectives sought were to examine the current rate of youths' unemployment and the implications on entrepreneurship adoption and Nigeria economic development; determine the key drivers of Asian Tigers economic growth from the 1960 to 2000 and the role of education; and ascertain the extent entrepreneurial education in higher institutions could boost Nigeria's economic development. The study adopted a combination of survey and desk research. Data analysis was qualitatively and quantitatively done. The quantitative was through Spearman's correlation coefficient. Results obtained reveal that the high rate of youths' unemployment and low rate of entrepreneurship adoption by the youths have significant negative effect on the nation's economic development. The key drivers of economic growth of the Four Asian Tigers between 1960 and 2000 were sound government policies on entrepreneurial, technical \& vocational education. That entrepreneurial education in higher institutions can significantly boost Nigeria's economic development. It was then recommended among other things that: The Nigerian youths must as matter of urgency take entrepreneurship much more serious, as a veritable complement to their educational attainment and as a surety for future greatness in the corporate world, and consequent boosting of the nation's economy.
\end{abstract}

Keywords: entrepreneurial education, higher institutions, youths' unemployment, economic development

\section{Introduction}

Entrepreneurship is the demonstration of skills, knowledge, ability and attitude in the management of a business enterprise. It involves risks, decision-making, organizational and managerial competence on the part of the entrepreneur in order to effectively manage a business venture in our global competitive market place. It is the aggregation of the myriads of diverse entrepreneurial productivities, marketing of same and the pool of consequent accrued resources that account largely for national development. There, lies the success story of the Asian tigers that swept and nearly dominated the global economy from the 1970s to 2000. All these entail that if you want to run a business successfully, you must be armed with knowledge of what entrepreneurship is all about and the basic managerial, accounting, statutory cum legal and physical requirements for achieving the goal. It was the foregoing that informed the introduction and emphasis on entrepreneurship curriculum in Nigerian universities by the National Universities' Commission (NUC).

Meanwhile, this paper is focused on shedding more light on the place of entrepreneurship education as a veritable tool for national development and a model for harnessing economic growth especially in a dire period of economic recession as we have in the country today, by drawing lessons from the experiences of the Asian tigers. Barro (1998) observed that until recent years, many East Asian countries popularly called the four Asian Tigers-Hong Kong, Singapore, South Korea and Taiwan, where growth rates of real per capita gross domestic product from 1960 to 2000 were around 6\% per year were widely regarded as economic miracles. Others like Indonesia, Malaysia, Thailand and China also made remarkable economic records in those years. These performances placed this East Asian group at the top of the world's growth list. According to Mascelluti (2015), the countries that grew the most and became the examples of an extraordinary growth process in the dominant years of the Asian tigers were the Four Asian Tigers, namely Hong Kong, Singapore, South Korea and Taiwan. 


\subsection{Statement of the Problem}

The stuttering growth of the Nigerian economy in critical sectors like small and medium-scale enterprises (SMEs) and the consequent growing rate of unemployment amongst the country's youth population especially the young graduates has been a cause for concern to all well-meaning citizens of the country. All efforts by previous administrations at boosting the country's economic growth and checkmating youths' unemployment through various schemes like the National Directorate of Employment (NDE) programme, and many more, failed.

Eze, Odigbo \& Ehikwe (2015) point out that it is one thing to start a business and another to achieve organisational survival, success and growth. Their study also reveals that sustaining and growing remains a big challenge for many Nigerian enterprises, especially during periods of economic down-turns, as we have today. This calls for astute entrepreneurial education for the acquisition of requisite knowledge, skills and attitude that serve as guarantor for long-term business development, survival and growth, more so, in this era of diffusive youths' unemployment in the country. A report from the Rise Network (2013) showed that the country's overall unemployment rate in 2011 was 23.9 percent, with youths' unemployment accounting for over 50 percent of that.

The National Bureau of Statistics (NBS) on its own admitted in its "2012 National Baseline Youth Survey Report" issued in Abuja that 54 per cent of Nigerian youths were unemployed in 2012, while the Central Bank of Nigeria reports that 80 per cent of Nigerian youths were without jobs in 2014 (CBN, 2014). With all these points in view, could entrepreneurship education serve as the driver for the survival of small and medium-scale enterprises in Nigeria, curbing youths' unemployment and consequently boosting the nation's economic development? Finding answers to this poser, is the major thrust of this analysis.

\subsection{Objectives of the Study}

The main objective of this situation analysis study was to ascertain the place of entrepreneurship education in promoting economic and national development in Nigeria, lessons from the Asian Tigers. The specific objectives were:

1) To examine the current rate of youths' unemployment and the implications on entrepreneurship adoption and Nigeria economic development.

2) To determine the key drivers of Asian Tigers economic growth from the 1960 to 2000 and the role of education.

3) To ascertain the extent entrepreneurial education in higher institutions could boost Nigeria's economic development.

\section{Literature Review}

\subsection{Theoretical Framework: The Theory of Economic Growth}

Theories of economic growth focus on the aggregation of goods and services produced in a nation over a long period of time. The neo-classical theorists believe that for a nation to witness economic growth there must be diminishing returns in capital and labour followed by technological advancement (Economicshelp.org, 2007). Another school of thought believes that economic growth must be linked to the level of poverty, standard of living index and general citizens' welfare in a country. Belonging to this group is Mascelluti (2015) who observes that economic growth is a macroeconomic phenomenon that explains the remarkable differences in income and standards of living across countries. It is fundamental in order to address issues concerning differences in the speed of growth and the level of poverty across countries. Another school of economist theorists measure economic growth in terms of the unit of the national gross domestic product (GDP). The GDP they say, is a measure of the value of all of the goods and services produced in a country in a year (Weil, 2003). Blanchard, Amighini and Giavazzi (2011) stated that GDP is the value of the final goods and services produced in the economy or the sum total of the value added of all firms, which is defined as the value of its production minus the value of the intermediate goods used in production. From the foregoing, therefore, the GDP can be estimated both from the production side, the income side and the standard of living side.

Hence, measuring economic growth, some economists compare the different living standards across countries and their relative currencies with the use of purchasing power parity exchange rates. Again, the use of output per capita, $Y N$, which involves the division of real output by the size of the population in a country, gives more reliable results when measuring economic progress and comparing different incomes. The importance of output per capita relies on the fact that it allows to derive differences in living standards, the soul of human happiness (Mascelluti, 2015). The implications of all these, is that successful entrepreneurship is a sine qua non for improved citizens' welfare and standard of living, economic growth and national development. 


\subsection{Entrepreneurship and Development: The Nexus}

Ait.org (2014), said the entrepreneur is one who is willing to bear the risk of a new venture if there is a significant chance for profit. He also plays the role of an innovator who markets his innovation. He develops new goods or processes that the market demands are not currently being supplied. Drucker (2005) observes that the entrepreneur is someone who actually searches for change, responds to it, and exploits change as an opportunity.

The U.S. Department of State Bureau of International Information Programs reports that most economists today agree that entrepreneurship is a necessary ingredient for stimulating economic growth and employment opportunities in all societies. In the developing world, successful small businesses are the primary engines of job creation, income growth, and poverty reduction. Therefore, in the developing world, government support for entrepreneurship is a crucial strategy for economic development (Ait.org, 2014). Hence, the Organization for Economic Cooperation and Development (OECD, 2003) advised that policies to foster entrepreneurship are essential to job creation and economic growth. This must have informed the priority place being given to entrepreneurship by the Nigerian government through various agencies, and the emphasis on entrepreneurship as a compulsory course for all students in the University of Calabar today. The U.S. Department of State Bureau of International Information Programs listed some personal attributes and skills that most successful entrepreneurs share in common to include: creativity, dedication, determination, flexibility, leadership, passion and self-confidence (Ait.org, 2014).

\subsection{Economic Growth and National Development}

Palmer (2012) notes that economic growth refers to an increase in the productive capacity of an economy as a result of the economy capable of producing additional quantities of goods and services. Normally standard of living is measured by the quantity of goods and services available to citizens in a country, so that economic growth is synonymous with an increase in the general standard of living.

On the other hand, national development entails the ability of a nation to improve the lives of its citizens. The measures of the improvement include material, such as an increase in the gross domestic product (GDP), or social, such as literacy rates, educational levels and availability of healthcare (Reference.com, 2015). Mindful of this fact, Akinyemi (2015), asserts that economic growth is different from national development, because national development comes only when the citizens' standard of living is growing in line with the economic growth. Maekae (2013) added that education is critical to national development, because quality education promotes citizens' level of productivity.

\subsection{Graduate Unemployment in Nigeria and Economic Development}

According to the Central Bank of Nigeria, 80 per cent of Nigerian youths were without jobs in 2014 (CBN, 2014). This is despite repeated figures released by the National Bureau of Statistics indicating that the Nigerian economy was experiencing positive growth rate. The National Bureau of Statistics (NBS) on its own admitted that 54 per cent of Nigerian youths were unemployed in 2012. This was contained in the "2012 National Baseline Youth Survey Report" issued in Abuja by the NBS in collaboration with the Federal Ministry of Youth Development (NBS, 2013). According to Sunnews (2014), the gravity of Nigeria's unemployment problem, especially graduate unemployment, is reflected by the trampling of graduate job seekers to death during stampedes at a 2013 Nigeria Immigration Service (NIS) recruitment drive across the country. That incident, alone, tells us that something needs to be done urgently to address the scourge of unemployment in the country. World Bank statistics in 2013 put the number of Nigerians living in destitution at 100 million, while its 2014 report put Nigeria among the five poorest countries in the world. The high rate of unemployment and low per capita income in the country are just two of the indices used by the World Bank in arriving at this assessment. All levels of government in the country need to be reminded that unemployment, especially among youths, is a time bomb for any country (Eze, Odigbo, \& Ehikwe, 2015; Sunnews, 2014).

In the same vein, Omeje (2005) in Eze, Odigbo \& Ehikwe (2015), reports that a staggering and growing level of youth unemployment in Nigeria, leading to hopelessness, restiveness and feelings of frustration, often precipitates or fuels violent conflicts in the country. High population growth rate amid unsatisfactory economic performance compounds the problem of youth unemployment in Nigeria. There is a markedly unfavourable imbalance between Nigeria's population growth rate and economic performance. Expansion of the economy to create employment opportunities for young school leavers and graduates has been rather sluggish. This heightens the risk and incidents of anti-establishment protests and frustration-related violence. The frustration and vulnerability of the youths make it possible for them to be recruited, inspired or hired for violence with relative ease. In the midst of mass misery and poverty, violence is seen and promoted as an economic opportunity by many subalterns and jobless youths (Omeje, 2005). This phenomenon resonates with the greed versus grievance 
theory of Paul Collier \& Anke Hoeffler (2002).

It is unfortunate that two years after, the announcement by the present Government of Nigeria to confront the problem of graduates' unemployment frontally, through a massive youths' agricultural programme is yet to be matched with significant action. The government had promised to collaborate with States and Local Governments to innovatively fund youths in commercial agribusiness programmes and launch Agricultural Support Programmes that will drive agricultural land development and mechanization (Nigerianmonitor, 2015; Newsheadline, 2015). This very one seems to go the way of the numerous youths' skills-acquisition, economic-empowerment and agricultural programmes had been tried in the past without much success. There was the school-to-land programme, the National Directorate of Employment skills-acquisition programme, the SURE-P and many more of such youths' empowerment and employment-generation programmes that didn't yield the expected result. All these informed the motivation for this critical appraisal of entrepreneurial education in higher institutions and Nigeria economic development for enhanced youths' skills-acquisition, employment and economic empowerment in Nigeria.

According to Ndifreke (2013), for Nigerian youths, especially the teeming unemployed graduates to contribute meaningfully to national economic development, the bulk of the task lies in the ability of the Nigerian government and leadership to provide an enabling environment where creativity and innovation is birthed, nurtured, grown and expanded with a sincere motive and drive towards economic development and people development. Ndifreke (2013) however, advised the youths of the country not to give up, but to arm themselves with extant skills-based knowledge, look inward for creativity, network with like minds and groups as a sure way getting out of their economic woods. In the same vein, Abasi (2013) pointed out that there could be a turning point, if Nigeria, appropriately harnesses its vast resources. If nothing is done to cater for sustainable employment and favourable economic conditions, considering Nigeria's current demography and the projected 200 million people in 2050; then the most populous African country would have faced undesired and dark days. So, it is incumbent on the leadership of this great country to start acting and thinking beyond the present. To cut youths' unemployment through farming, the rural areas of the country must be provided with basic amenities like clean pipe-borne water, electricity, good roads, functional healthcare and educational systems that will make the areas attractive and stem the tide of rural-urban migration (Eze, Odigbo, \& Ehikwe, 2015). Government should also assist to revamp the various cottage industries started by individuals in the country which failed to survive due to high operating energy costs, multiple taxation problems, dependence on imported raw materials and many other problems (Abasi, 2013).

\subsection{Nigeria Unemployment Rate, 2006-2018}

An authoritative report from Nigeria's National Bureau of Statistics (NBS, 2018), reveal that unemployment rate in the country increased to 18.80 percent in the third quarter of 2017 from 16.20 percent in the second quarter of 2017. Unemployment Rate in Nigeria averaged 10.63 percent from 2006 until 2017, reaching an all-time high of 19.70 percent in the fourth quarter of 2009 and a record low of 5.10 percent in the fourth quarter of 2010 . See Figure 1 for a graphic statistics of this.

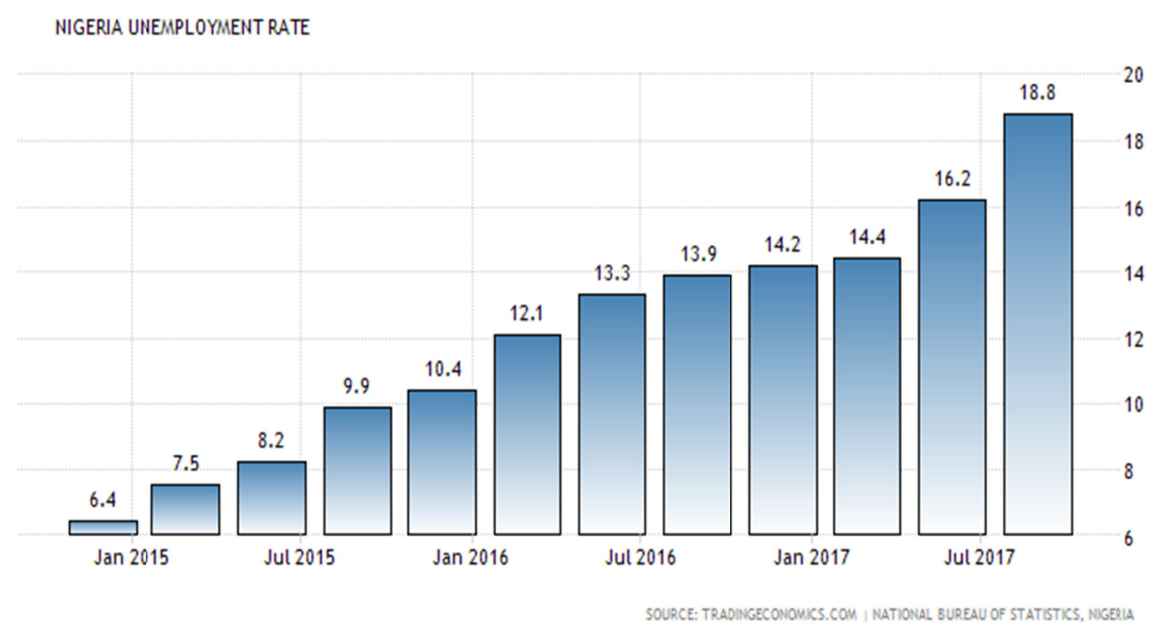

Figure 1. Nigeria's unemployment rate, 2006-2018

Source: National Bureau of Statistics (2018), Nigeria's unemployment rate.http://www.nigerianstat.gov.ng/ 
Table 1 gives a picture of the unemployment rate measurement of the number of people actively looking for a job as a percentage of the labour force in Nigeria in 2018. It provides a comparative report of Nigeria's 2018 unemployment rate with previous years. The data posts the historical high and low, short-term forecast and long-term prediction, economic calendar and survey consensus as at September, 2018.

Table 1. Number of people actively looking for jobs and the labour force in Nigeria, 2018

\begin{tabular}{lllllll}
\hline Nigeria Labour & Last & Previous & Highest & Lowest & Unit & \\
\hline Unemployment Rate & 18.80 & 16.20 & 19.70 & 5.10 & percent & {$[+]$} \\
Population & 190.89 & 185.99 & 190.89 & 45.14 & Million & {$[+]$} \\
Living Wage Family & 131700.00 & 131700.00 & 131700.00 & 131700.00 & NGN/Month & {$[+]$} \\
Living Wage Individual & 40100.00 & 40100.00 & 40100.00 & 40100.00 & NGN/Month & {$[+]$} \\
Employed Persons & 69090.00 & 70354.90 & 70665.90 & 66951.00 & Thousand & {$[+]$} \\
Employment Change & 187226.00 & 155444.00 & 499521.00 & 79465.00 & Jobs & {$[+]$} \\
Employment Rate & 81.20 & 83.80 & 93.60 & 81.20 & percent & {$[+]$} \\
Unemployed Persons & 15998.00 & 13585.20 & 15998.00 & 4672.00 & Thousand & {$[+]$} \\
Wages High Skilled & 57200.00 & 57200.00 & 57200.00 & 57200.00 & NGN/Month & {$[+]$} \\
Wages Low Skilled & 25500.00 & 25500.00 & 25500.00 & 25500.00 & NGN/Month & {$[+]$} \\
Youth Unemployment Rate & 33.10 & 29.50 & 33.10 & 11.70 & percent & {$[+]$} \\
\hline
\end{tabular}

\subsection{Importance of Entrepreneurship Education to Unemployed Youths}

The importance of entrepreneurship to unemployed youths, especially the Nigerian graduates cannot be underscored. They include:

1) The offering of the opportunity of being your own boss by choosing the type of business to do and with whom to do it. You decide what hours to work, as well as what to pay and whether to take vacations or not.

2) Entrepreneurship offers you a greater possibility of achieving significant financial rewards than working for someone else.

3) Entrepreneurship provides you the ability to be involved in the total operation of your business, from concept to design and creation, from sales to business operations and customer response.

4) Entrepreneurship offers you the prestige of being the person in charge.

5) Entrepreneurship gives you the opportunity to build equity, which can be kept, sold, or passed on to your sons and or daughters.

6) Entrepreneurship gives you an opportunity to contribute to national economic development, employment generation and social peace in your country like Aliko Dangote of Nigeria, Bill Gates of United States of America, Steve Jobs the co-founder of Apple, Mike Adenuga of Globacom, and many more.

\subsection{Entrepreneurial Education and National Economic Development}

The American Heritage School Dictionary (1977) defines education as the process of imparting or obtaining knowledge or skill from someone believed to have the knowledge or skill. Entrepreneurial education therefore, is the process of obtaining knowledge or receiving formal instruction in the principles and techniques of entrepreneurship for optimal performance in all areas of business. Etuk (2016) emphasizes that entrepreneurial education is one of the best ways to upward mobility in an expanding industrial society. Such education, however, should not comprise general education components alone, but it should serve to form a bridge to link what is learnt in the classroom with what obtains in industry, that is an educational form that can break the jinx between ordinary book knowledge (general education) and technico-vocational knowledge that combines the most needed technological know-how and skill that is relevant to industry. Odigbo, Eze and Ehikwe (2016), buttressed this viewpoint by pointing out that it was what led to the globally-acclaimed success of the Asian tigers between 1960s and 1990s.

According to Ogwo (2016), the poor state of affairs being experienced in the marketing of locally-produced goods in Nigeria, by both big and small-scale enterprise is attributable to a number of factors which include: lacuna in the interaction and synergy between marketing education and society on the one hand, and inadequacies in the intellectual preparation of marketers in Africa. Thomas (1986) cited in Ogwo (2016), outlines the requisite educational resources for successful entrepreneurship to include: (1). Planning skills. (2). Environmental awareness. (3). Organizational ability. (4). Segmentation/product development skills. (5). 
Behavior analysis skills. (6). Market research commissioning skills. (7). Information analysis skills. (8). Innovation management skills. (9). Strategic thinking skills. (10). Sales and advertising management and productivity management skills. (11). Marketing mix optimization skills. (12). Interdepartmental cooperation and conflict resolution skills. (13). Financial management skills. (14). Systems thinking skill. (15). Ability to comprehend long term interests of the company, and (16). Ability to 'market' marketing enthusiastically.

Anyanwu (2016), particularly harped on the need for the SMEs to acquire rudimentary research skills, as one of the educational resources and surest ways to enhance the growth of the SMEs in the country, because a problem recognized is half-solved. Research, he said, is all about generating relevant data, analyzing such data for information which will enable entrepreneurs to make informed decisions.

\section{Methodology}

The review is a situation analysis study (SAS) based on a combination of survey and desk research. The data from the survey were sourced from primary sources and quantitatively analysed, while data on the desk research came from extant literature and qualitatively analysed. Four countries popularly called the Asian Tigers (Hong Kong, Singapore, South Korea and Taiwan), were selected for the desk research, while three major commercial cities in South-East of Nigeria: Nnewi, Aba and Onitsha were selected for the survey.

\section{Data Presentation and Analysis}

4.1 Analysis of Research Objective 1: To Examine the Current Rate of Youths' Unemployment and the Implications on Entrepreneurship Adoption and Nigeria Economic Development

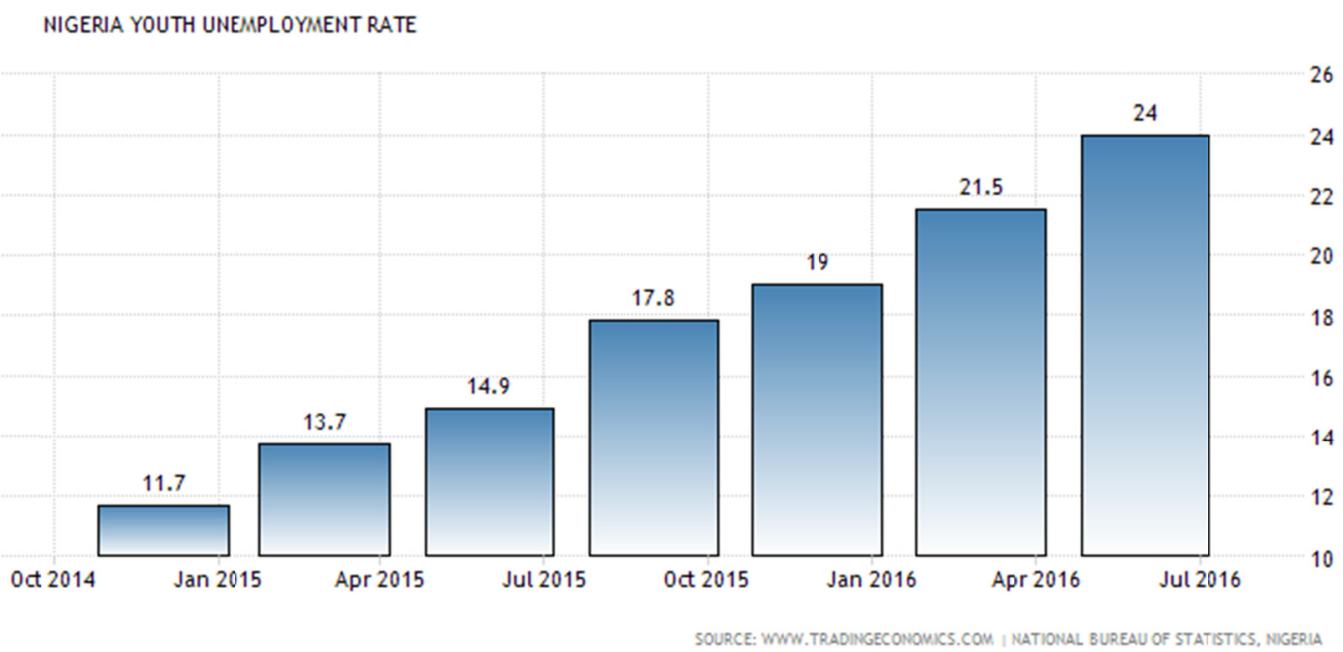

Figure 2. Nigeria Youth Unemployment Rate October 2014 to July 2016

Source: http://www.tradingeconomics.com/nigeria/youth-unemployment-rate

From figure 2 above, it could be seen that there is a trend of steady rise in youths' unemployment rate between October 2014 and July 2016. The implications of this is that youths who factor-in entrepreneurship into their future plan as either "option A" or their "option B" are wiser and ensured of a guaranteed successful future than those who do not. However, the high rate of youths' unemployment and low rate of entrepreneurship adoption by the youths, have significant negative effect on the nation's economic development. 
4.2 Analysis of Objective 2: To Determine the Key Drivers of Asian Tigers Economic Growth From the 1960 to 2000 and the Role of Education
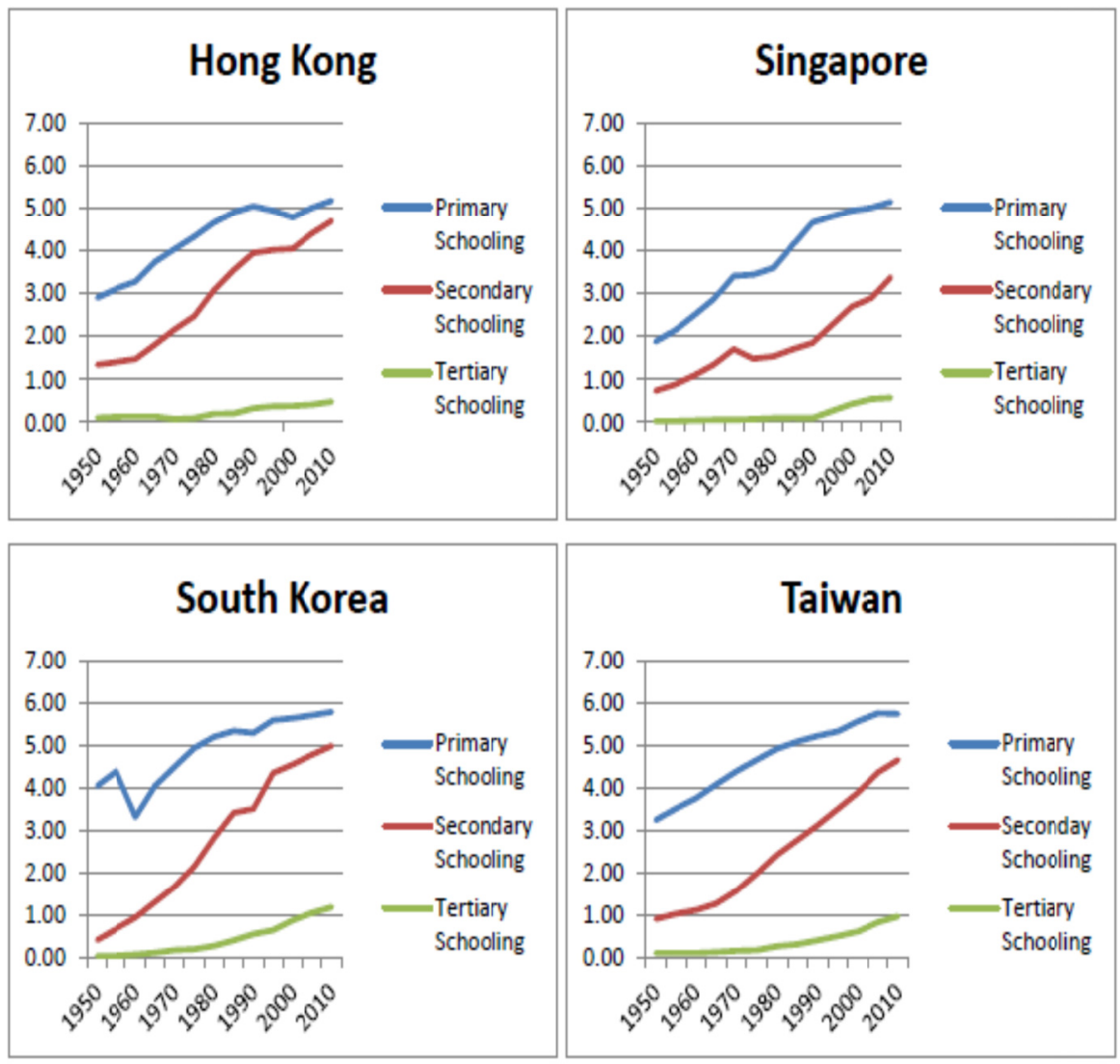

Source Exel, Barro and Lee Dataset

Figure 3. Asian Tigers economic growth from the 1960 to 2000 and the role of education.

Source: Mascelluti, Eleonora (2015). The Extraordinary Growth of the Four Asian Tigers. http://tesi.eprints.luiss.it/15269/1/176201.pdf

Figure 3 shows a steady economic growth rate that surprised the whole world by the four Asian Tigers between 1960 t0 2000. The main variables which accounted for the fast and sustainable growth of the Four Asian Tigers were sound government policies, entrepreneurial, technical \& vocational education. Here, higher education contributed insignificantly. This result finds support in Etuk (2016), which emphasizes that entrepreneurial education should not comprise general education components alone, but should serve to form a bridge to link what is learnt in the classroom with what obtains in industry, that is an educational form that can break the jinx between ordinary book knowledge (general education) and technico-vocational knowledge that combines the most needed technological know-how and skill that is relevant to industry.

\subsection{Analysis of Objective 3: To Ascertain the Extent Entrepreneurial Education in Higher Institutions Could Boost Nigeria's Economic Development}

This section was a survey where primary data sourced through structured question was used in the analysis. The area of study was three major commercial cities in South-East of Nigeria: Nnewi, Aba and Onitsha. The population of the study was 13,000 , comprising of students from two federal universities: The University of Nigeria, Enugu Campus, and Nnamdi Azikiwe University, Awka, with one state-owned university, the Enugu State University of Science and Technology. A sample size of 400 was statistically determined using Taro Yamane at 5\% margin of error. The instrument was structured in five-point Likert scale. Non-probability purposive sampling technique was used to distribute the questionnaire. Data analysis employed was through Spearman Correlation coefficient. Out of the 400 questionnaire copies distributed, 378 copies representing $94.50 \%$ were correctly completed and returned. The respondents were in the age range of 16 years to 30 years. 


\section{Test of Hypothesis on Objective 3:}

Ho: Entrepreneurial education in higher institutions cannot significantly boost Nigeria's economic development.

Hi: Entrepreneurial education in higher institutions can significantly boost Nigeria's economic development.

Test Statistics $=$ Spearman Correlation Coefficient $\left({ }^{\mathrm{r}} \mathrm{s}\right)$

Table 4. Statistical test of hypothesis 1

\begin{tabular}{lllllll}
\hline Options & Data 1 & Data 2 & Rank 1 & Rank 2 & D & $\mathrm{d}^{2}$ \\
\hline Strongly Agree & 160 & 123 & 4 & 4 & 5 & 0 \\
Agree & 173 & 137 & 5 & 2 & 0 & 0 \\
Undecided & 15 & 38 & 2 & 1 & 0 & 0 \\
Disagree & 17 & 36 & 3 & 3 & 2 & -2 \\
Strongly Disagree & 13 & 44 & 1 & & 4 \\
\hline
\end{tabular}

$\sum \mathrm{d}^{2}=0+0+0+4+4=8$

So $r_{S}=1-2 \times \sum d^{2} / n\left(n^{2}-1\right)$

$\mathrm{r}_{\mathrm{S}}=1-(2 \times 8) / \mathrm{n}\left(\mathrm{n}^{2}-1\right)$

$\mathrm{r}_{\mathrm{S}}=1-2 \times 8 / 5\left(5^{2}-1\right)$

$\mathrm{r}_{\mathrm{S}}=1-0.133=0.866$

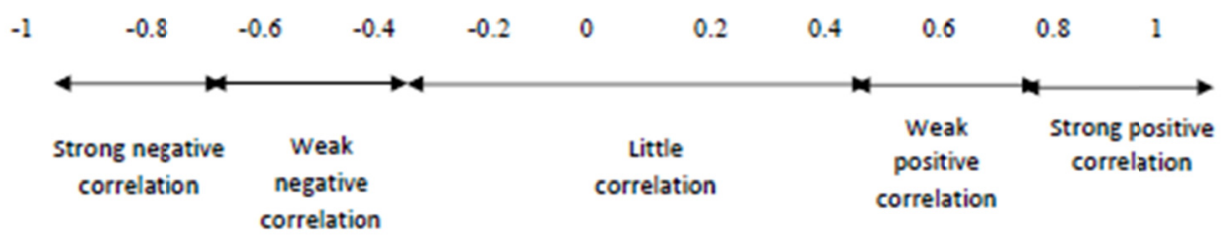

Figure 3. Interpretation of the result of the spearman correlation coefficient

Since the result of the Spearman Correlation Coefficient $\left({ }^{\mathrm{r}} \mathrm{s}=0.866\right)$ shows a strong positive correlation, we hereby reject the Ho and accept the Hi which says that "entrepreneurial education in higher institutions can significantly boost Nigeria's economic development."

\section{Summary of Results}

A summary of the results obtained were that:

1) The high rate of youths' unemployment and low rate of entrepreneurship adoption by the youths, have significant negative effect on the nation's economic development.

2) The main variables which accounted for the economic growth of the Four Asian Tigers between 1960-2000 were sound government policies, entrepreneurial, technical \& vocational education.

3) Entrepreneurial education in higher institutions can significantly boost Nigeria's economic development.

\section{Discussion of Findings}

Favourable government policies devoid of policy inconsistencies were among the major drivers of the Asian Tigers economy. There were also aggressive efforts into international trade founded on a policy of reduction in tariffs for both import and export goods, and the decrease in the restrictions to trade and in the barriers for international inflows of capital.

The implications of this result are that the government of Nigeria must at all times ensure that policies that motivate and encourage the entrepreneurial spirit in the Nigerian youth are put in place. Effective implementation of such policies must also be ensured. A situation where such laudable programmes in the past were killed through the ambit of corruption can no longer be tolerated in this country.

Another second factor that accounted for the fast growth of the economies of the four Asian Tigers was their governments' emphasis on entrepreneurial, technical and vocational education within the period under review. 
Economists over the world, use human capital development as one of the factors for measuring the productivity of a country. Entrepreneurial, technical and vocational education led to huge accumulation of skilled human capital, which played a critical role in the incredible growth of the Asian Tigers.

The governments' of the four Asian Tigers promoted more of technical and vocational studies and as there were lowered rates of tertiary education enrolment. As could be seen more students were enrolled in technical schools following the governments' desire to meet the needs of the future industry. The strong support of the technical and vocational schools reduced the space for the enrollment in tertiary education which was perceived as an even more egalitarian road.

The implication of this result is that entrepreneurship, technical and vocational skills as being taught by the University of Calabar Entrepreneurship Development Centre, holds the key to economic greatness for the Nigerian youth.

\section{Recommendations and Lessons from the Asian Tigers}

The lessons derivable from the Asian economic miracle of the 1960s to 2000 for successful youths' entrepreneurships culture in Nigeria include the following:

1) Massive entrepreneurship by citizens of any country is the key to economic and national greatness.

2) If the Asian Tigers' population with low educational rate could perform such a globally acclaimed economic feat, the Nigerian population with a youth population with higher literacy rate and tertiary educational attainments could even do better, with faith.

3) The Nigerian youths must as matter of urgency take entrepreneurship much more serious, as a veritable complement to their educational attainment and as a surety for future greatness in the corporate world.

4) For entrepreneurship to thrive, there must also be a well-functioning financial sector as an engine for economic activities.

5) The Nigerian youth must not look down on the powers inherent in small beginnings, because over 90 percent of the businesses in the Asian Tigers were small-scale family-owned and family financed businesses. As the scripture enjoins we should not neglect the days of our little beginnings.

\section{References}

Ait.org. (2014). Entrepreneurship. Retrieved from https://www.ait.org.tw/infousa/zhtw/DOCS/enterp.pdf

Anyanwu, A. (2016). Enhancing the Growth of SMEs Through Academic Research Programmes. In A. E. Ehikwe, F. J. Eze, B. B. Esu, \& B. E. Odigbo (Eds.), Marketing education and professionalism in Africa: The town and gown linkages (p. 27). Lagos: National Institute of Marketing of Nigeria.

Barro, R. J. (1998). The East Asian Tigers Have Plenty to Roar About. Business Week, April 27, p. 24.

CBN. (2014). $80 \%$ Of Nigerian Youths Are Unemployed-CBN Official. Retrieved from http://www.informationng.com/tag/national-bureau-of-statistics

Drucker, P. F. (2005). Innovation and Entrepreneurship. New York: Harper.

Etuk, E. J. (2016). Marketing education and industry linkages in Nigeria: the role of public policy. In A. E. Ehikwe, F. J. Eze, B. B. Esu, \& B. E. Odigbo (Eds.), Marketing education and professionalism in Africa: The town and gown linkages (p. 17). Lagos: National Institute of Marketing of Nigeria.

Eze, F. J., Ehikwe, A., \& Odigbo, B. (2015). Appraisal of word-of-mouth communications as survival strategy for small and medium scale enterprises (SMEs) during economic down-turn in Nigeria, Asian Academic Research Journal of Social Sciences \& Humanities, 1(34), 1-12.

Eze, F. J., Odigbo, B. E., \& Ehikwe, A. E. (2015). Marketing Communications Strategy for Curbing Youths'Unemployment through Farming in Nigeria. Journal of Economics and Sustainable Development, $6(16), 45-52$.

Mascelluti, E. (2015). The Extraordinary Growth of the Four Asian Tigers. Retrieved from http://tesi.eprints.luiss.it/15269/1/176201.pdf

National Bureau of Statistics. (2018). Nigeria's unemployment rate. Retrieved from http://www.nigerianstat.gov.ng/

NBS. (2013). 54\% of Nigerian Youths Were Unemployed in 2012. Retrieved from http://www.informationng.com/2013/12/54-of-nigerian-youths-were-without-jobs-in-2012-says-nbs.html 
Ogwo, O. E. (2016). Marketing education and professionalism in Africa: The town and gown linkages. In A. E. Ehikwe, F. J. Eze, B. B. Esu, \& B. E. Odigbo (Eds.), Marketing education and professionalism in Africa: The town and gown linkages (p. 2). Lagos: National Institute of Marketing of Nigeria.

Okpara, G. S., \& Agu, G. (2016). Comparative Service Quality Metrics in Regular and Non-Regular Undergraduate Marketing Programmes: Implications for Marketing Education and Professionalism. In A. E. Ehikwe, F. J. Eze, B. B. Esu, \& B. E. Odigbo (Eds.), Marketing education and professionalism in Africa: The town and gown linkages (p. 41). Lagos: National Institute of Marketing of Nigeria.

Olivier, B., Alessia, A., \& Francesco, G. (2011). Macroeconomics, a European perspective. Prentice Hall Inc.

Palmer, N. T. (2012). The Importance of Economic Growth. Certified Public Accountants, March, p. 1.

Reference.com. (2015). What is national development. Retrieved from http://www. reference.com/ national development.html

Rise Network. (2013). Youth Unemployment in Nigeria: Shocking Statistics, Facts and Why the Future May Not $\mathrm{Be} \quad$ So $\quad$ Bright $\quad$ Afterall. $\quad$ Retrieved from http://risenetworks.org/2013/05/16/youth-unemployment-in-nigeria-is-there-hope-for-nigerian-youth/

Thomas, M. (1986). The Professional Marketing Manager. Journal of Marketing Management, 2(1), 1-6. https://doi.org/10.1080/0267257X.1986.9963996

United Nations Development Programme. (2004). Commission on the Private Sector and Development. Unleashing Entrepreneurship: Making Business Work for the Poor. New York: United Nations Development Programme Publication.

Weil, D. N. (2003). Economic Growth (3rd ed.). New Jersey: Pearson, p. 112.

\section{Copyrights}

Copyright for this article is retained by the author, with first publication rights granted to the journal.

This is an open-access article distributed under the terms and conditions of the Creative Commons Attribution license (http://creativecommons.org/licenses/by/4.0/). 